\title{
The Internal Reconstruction of the Phonemes Proto Busoa Language
}

\author{
Asrul Nazar ${ }^{1 *}$, Nadir La Djamudi ${ }^{1}$, L.M. Azhar Sa'ban ${ }^{2}$ \\ ${ }^{1}$ Faculty of Teacher Training and Education, Universitas Muhammadiyah Buton, Baubau, Indonesia \\ ${ }^{2}$ Faculty of Social and Political Sciences, Universitas Muhammadiyah Buton, Baubau, Indonesia \\ "Corresponding author. Email: asrulnazar@gmail.com
}

\begin{abstract}
As the language is endangered, language Busoa should the effort of documenting the language as a form of keeping the intellectual property of the ancestors. The purpose of this study was to determine the phonemes of proto-language Busoa. The method in this research is descriptive qualitative method with the techniques of reconstruction of the internal. The results showed that the phoneme vocal proto-Language Busoa there are 5 phonemes of vowels, namely vowels front high $/ \mathrm{i} /$, high back $/ * \mathrm{u} /$, the front of the middle of the $/ * \mathrm{e} /$, the middle of the back $/ * \mathrm{o} /$, and the vowel menen middle-low $/ * \mathrm{a} /$. While on the phonemes of consonants proto there are 15 pieces, namely: ${ }^{*} \mathrm{p},{ }^{*} \mathrm{~b},{ }^{*} \mathrm{t},{ }^{*} \mathrm{~d},{ }^{*} \mathrm{j},{ }^{*} \mathrm{k},{ }^{*} \mathrm{~g},{ }^{*} \beta,{ }^{*} \mathrm{~s},{ }^{*} \mathrm{R},{ }^{*} \mathrm{~h},{ }^{*} \mathrm{l},{ }^{*} \mathrm{~m},{ }^{*} \mathrm{n}$, and $\hat{\mathrm{b}}$. The conclusion of this research is on the phonemes of Vowels proto there are 5 pieces and consonants proto contained 15 pieces.
\end{abstract}

Keywords: reconstruction, phonemes proto, Busoa

\section{INTRODUCTION}

Language is a system of sound emblem that has an arbitrary and conventional meaning [1]. The languages that exist in the archipelago area is a historical fact for the life of the language. Language is dynamic due to the dynamism of the language of the people. Indonesia has a variety of regional languages as a link language between region, although we have the Indonesian language as the national language. The regional languages are widespread from Sabang to Merauke. Regional languages are local products as a form of expression or identity of the community, which are passed down as a form of cultural heritage. Those languages, some of which evolved in an established direction, and some were of extinction.

In Indonesia there are 742 languages, 737 are languages that are still alive or still used by the narrative [2]. Based on the results of the research conducted by the Ministry of Education and Culture language development (Kemendikbud), it shows that the possibility of 139 ethnic/regional language in Indonesia. The new language body identifies 617 languages from more than 700 languages, the number of endangered languages reaches 139 (language), and 15 regional languages the status is declared extinct. Geographically the spread of the almost extinct regional language is Kalimantan there is 1 language; The Moluccas are 22 languages; Papua and Halmahera have 67 languages; Sulawesi has 36 languages; Sumatera has two languages; and Timor-Flores, Bima, and Sumbawa in East Nusa Tenggara there are 11 languages [3].

The problem of regional language that is driving today is the rescue of local languages in the area of extinction is both a detainment and documentation of languages. The extinction of a language is a natural process of every language. Extinction of the local languages is a phenomenon that must be addressed in a wise. Various anticipatory and serious efforts need to be done. Some factors are the cause of a language, which is (1) a language speaker with no natural disasters; (2) deliberately killed by his narrative; and (3) interethnic marriage. This research is done to document the language of Busoa in the Batauga District, South Buton Regency. The threat of extinction of these areas needs attention because the extinction of the language is the same as the extinction of human civilization using it.

The language of Busoa (hereinafter abbreviated as BBs) is a language in Buton Island, Southeast Sulawesi province, not long ago (the year 2016) was found by researchers from the provincial language office of Southeast Sulawesi. BBs speakers are currently predicted to live about 635 people, from a population of 1,728 , consisting of males of 860 people and females as many as 868 people. BBs is one of the most vulnerable languages of extinction because the language is flanked by the majority languages, such as Wolio, Muna, and Ciacia. Based on the explanation above, the focus of this research is the study of the language documentation through the internal reconstruction of the phonemes Proto BBS and aims to determine the phoneme proto on BBs.

\section{METHOD}

The methods in this study are qualitative methods. The qualitative method is used to compare the linguistic data based on linguistics facts based on reconstruction work steps according to Crowley [4]. The research Data used is the equivalent words sourced from the informant based on the criteria established [5]. The Data was collected using the Sulawesi Wordbook Umbrella Wordlist which was published by the Summer Institute of Linguistics (SIL) for 487 words to analyze the languages of Sulawesi.

The result of this reconstruction is called Etimon. Etimon is proto of the word that lowers Leksem-Leksem on the languages of the relatives. In other words, Etimon is proto 
Table 2 Reconstructive proto phonemes the last result of the reconstruction that is hypothesized as the original form of derivative languages before they separated thousands of years ago, in addition to determining the criteria of language grouping through Innovation. This shape is based on an asterisk [6]

\section{RESULTS AND CONCLUSIONS}

This research shows that the reconstruction of the phoneme Proto is done with a regular and system-based working step. These reconstruct measures are made based on the linguistic facts of the data obtained in the field, namely data from the informant that is taken based on the number of Dusun in Busoa village. The reconstruction work measures, i.e., devise potentially compatible words among the related variants. The vocabulary used in this study is the Sulawesi Wordbook Umbrella Wordlist. The vocabulary is used as a basic vocabulary as a special vocabulary for analyzing languages in Sulawesi, published by the Summer Institute of Linguistics (SIL) of 487 words. The vocabulary is a collection of the words of limbs, public relations, animals, pronouns, vegetation, the natural world, man-made, adjectives, grammar, numbers, position, time, verb, habits, and question words.

Furthermore, it determines the one cognate word contained in the BBs group. The words used in comparative language are the one cognate word that are a reflection of the results of the reflection of the heritage history of a common source of language. The word determination cognate did by looking at the similarities of the form and meaning of the group of Languages. Lastly, the reconstruction of each phoneme contained in the same word pair is compared. The reconstruction or restoration of the phonemes proto $\mathrm{BCc}$ group is done by comparing the correspondence set on the word cognate in the related words. Setlist of correspondence based on BBs linguistic facts. Note the Table 1.

Table 1 Correspondence set

\begin{tabular}{|llll|}
\hline DB & DW & DT & DL \\
\hline $\mathrm{a}$ & $\mathrm{a}$ & $\mathrm{a}$ & $\mathrm{a}$ \\
$\mathrm{i}$ & $\mathrm{i}$ & $\mathrm{i}$ & $\mathrm{i}$ \\
$\mathrm{u}$ & $\mathrm{u}$ & $\mathrm{u}$ & $\mathrm{u}$ \\
$\mathrm{e}$ & $\mathrm{e}$ & $\mathrm{e}$ & $\mathrm{e}$ \\
$\mathrm{o}$ & $\mathrm{o}$ & $\mathrm{o}$ & $\mathrm{o}$ \\
$\mathrm{p}$ & $\mathrm{p}$ & $\mathrm{p}$ & $\mathrm{p}$ \\
$\mathrm{b}$ & $\mathrm{b}$ & $\mathrm{b}$ & $\mathrm{b}$ \\
$\mathrm{m}$ & $\mathrm{m}$ & $\mathrm{m}$ & $\mathrm{m}$ \\
$\beta$ & $\beta$ & $\mathrm{b}$ & $\beta$ \\
$\mathrm{b}$ & $\mathrm{b}$ & $\mathrm{b}$ & $\mathrm{b}$ \\
$\mathrm{t}$ & $\mathrm{t}$ & $\mathrm{t}$ & $\mathrm{t}$ \\
$\mathrm{n}$ & $\mathrm{n}$ & $\mathrm{n}$ & $\mathrm{n}$ \\
$\mathrm{s}$ & $\mathrm{s}$ & $\mathrm{s}$ & $\mathrm{s}$ \\
$\mathrm{R}$ & $\mathrm{R}$ & $\mathrm{R}$ & $\mathrm{R}$ \\
$\mathrm{d}$ & $\mathrm{d}$ & $\mathrm{d}$ & $\mathrm{d}$ \\
$\mathrm{j}$ & $\mathrm{j}$ & $\mathrm{j}$ & $\mathrm{j}$ \\
$\mathrm{k}$ & $\mathrm{k}$ & $\mathrm{k}$ & $\mathrm{k}$ \\
$\mathrm{g}$ & $\mathrm{g}$ & $\mathrm{g}$ & $\mathrm{g}$ \\
$\mathrm{h}$ & $\mathrm{h}$ & $\mathrm{h}$ & $\mathrm{h}$ \\
\hline
\end{tabular}

Based on the correspondence set, there are no different phonemes, it is immediately designated as a proto phoneme. Note the Table 2.

\begin{tabular}{|ccccc|}
\hline DB & DW & DT & DL & Proto Phonemes \\
\hline $\mathrm{a}$ & $\mathrm{a}$ & $\mathrm{a}$ & $\mathrm{a}$ & $*_{\mathrm{a}}$ \\
$\mathrm{i}$ & $\mathrm{i}$ & $\mathrm{i}$ & $\mathrm{i}$ & $*_{\mathrm{i}}$ \\
$\mathrm{u}$ & $\mathrm{u}$ & $\mathrm{u}$ & $\mathrm{u}$ & $*_{\mathrm{u}}$ \\
$\mathrm{e}$ & $\mathrm{e}$ & $\mathrm{e}$ & $\mathrm{e}$ & $*_{\mathrm{e}}$ \\
$\mathrm{o}$ & $\mathrm{o}$ & $\mathrm{o}$ & $\mathrm{o}$ & $*_{\mathrm{o}}$ \\
$\mathrm{p}$ & $\mathrm{p}$ & $\mathrm{p}$ & $\mathrm{p}$ & $*_{\mathrm{p}}$ \\
$\mathrm{b}$ & $\mathrm{b}$ & $\mathrm{b}$ & $\mathrm{b}$ & $*_{\mathrm{b}}$ \\
\hline $\mathrm{m}$ & $\mathrm{m}$ & $\mathrm{m}$ & $\mathrm{m}$ & $*_{\mathrm{m}}$ \\
$\beta$ & $\mathrm{\beta}$ & $\beta$ & $\beta$ & ${ }_{\mathrm{\beta}}$ \\
$\mathrm{b}$ & $\mathrm{b}$ & $\mathrm{b}$ & $\mathrm{b}$ & $*_{\mathrm{b}}$ \\
$\mathrm{t}$ & $\mathrm{t}$ & $\mathrm{t}$ & $\mathrm{t}$ & $*_{\mathrm{t}}$ \\
$\mathrm{n}$ & $\mathrm{n}$ & $\mathrm{n}$ & $\mathrm{n}$ & $*_{\mathrm{n}}$ \\
$\mathrm{s}$ & $\mathrm{s}$ & $\mathrm{s}$ & $\mathrm{s}$ & $*_{\mathrm{s}}$ \\
$\mathrm{R}$ & $\mathrm{R}$ & $\mathrm{R}$ & $\mathrm{R}$ & $*_{\mathrm{R}}$ \\
$\mathrm{d}$ & $\mathrm{d}$ & $\mathrm{d}$ & $\mathrm{d}$ & $*_{\mathrm{d}}$ \\
$\mathrm{j}$ & $\mathrm{j}$ & $\mathrm{j}$ & $\mathrm{j}$ & $*_{\mathrm{j}}$ \\
$\mathrm{k}$ & $\mathrm{k}$ & $\mathrm{k}$ & $\mathrm{k}$ & $*_{\mathrm{k}}$ \\
$\mathrm{g}$ & $\mathrm{g}$ & $\mathrm{g}$ & $\mathrm{g}$ & $*_{\mathrm{h}}$ \\
$\mathrm{h}$ & $\mathrm{h}$ & $\mathrm{h}$ & $\mathrm{h}$ & \\
\hline
\end{tabular}

The phonemes, which have been assigned by the propositions, can be inventoried based on their position and articulate. If the whole phoneme has been assigned the proximate phoneme, it can be created an inventory table based on the position and manner of its articulate. Inventory starts with a vocal proto as follows.

Table 3 Vocal inventory

\begin{tabular}{|cccc|}
\hline Position & Front & Central & Back \\
\hline High & $*_{\mathrm{i}}$ & & $*_{\mathrm{u}}$ \\
Central & $*_{\mathrm{e}}$ & $*_{\mathrm{a}}$ & $*_{\mathrm{o}}$ \\
Low & & & \\
\hline
\end{tabular}

A vocal phoneme spread on BBs can be formulated as follows.

Table 4 Vocal dispersion formula

\begin{tabular}{|cccc|}
\hline Vocal & Early & Central & End \\
\hline$/ * \mathrm{i} /$ & {$[\mathrm{a}-]$} & {$[-\mathrm{a}-]$} & {$[-\mathrm{a}]$} \\
$/ * \mathrm{u} /$ & {$[\mathrm{u}-]$} & {$[-\mathrm{u}-]$} & {$[-\mathrm{u}]$} \\
$/ * \mathrm{e} /$ & {$[\mathrm{e}-]$} & {$[-\mathrm{e}-]$} & {$[-\mathrm{e}]$} \\
$/ * \mathrm{o} /$ & {$[\mathrm{o}-]$} & {$[-\mathrm{o}-]$} & {$[-\mathrm{o}]$} \\
$/ * \mathrm{a} /$ & {$[\mathrm{a}-]$} & {$[-\mathrm{a}-]$} & {$[-\mathrm{a}]$} \\
\hline
\end{tabular}

Table 5 Consonant proto inventory

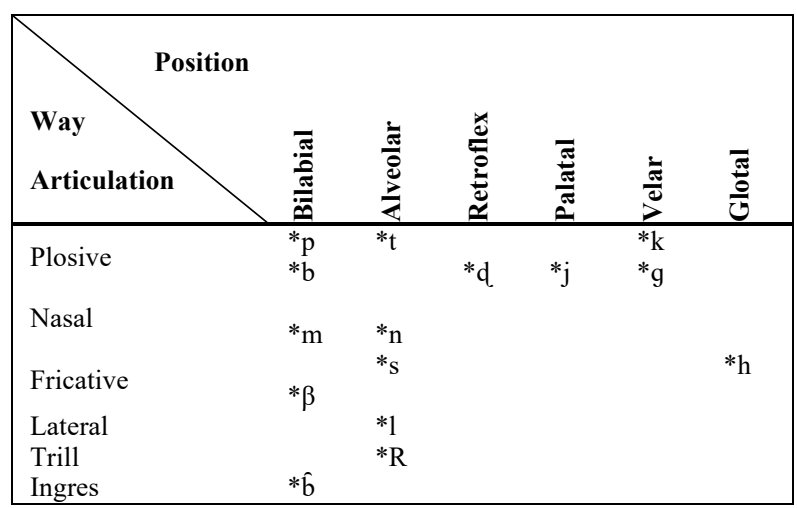




\section{REFERENCES}

follows.

Table 6 Consonant dispersion formula

\begin{tabular}{|cccc|}
\hline Consonant & prefix & infix & suffix \\
\hline$/ * \mathrm{p} /$ & {$[\mathrm{p}-]$} & {$[-\mathrm{p}-]$} & $-\varnothing$ \\
$/ * \mathrm{~b} /$ & {$[\mathrm{b}-]$} & {$[-\mathrm{b}-]$} & $-\varnothing$ \\
$/ * \mathrm{t} /$ & {$[\mathrm{t}-]$} & {$[-\mathrm{t}-]$} & $-\varnothing$ \\
$/ * \mathrm{~d} /$ & {$[\mathrm{d}-]$} & {$[-\mathrm{c}-]$} & $-\varnothing$ \\
$/ * \mathrm{j} /$ & {$[\mathrm{j}-]$} & {$[-\mathrm{j}-]$} & $-\varnothing$ \\
$/ * \mathrm{k} /$ & {$[\mathrm{k}-]$} & {$[-\mathrm{k}-]$} & $-\varnothing$ \\
$/ * \mathrm{~g} /$ & {$[\mathrm{g}-]$} & {$[-\mathrm{g}-]$} & $-\varnothing$ \\
$/ * \mathrm{~m} /$ & {$[\mathrm{m}-]$} & {$[-\mathrm{m}-]$} & $-\varnothing$ \\
$/ * \mathrm{n} /$ & {$[\mathrm{n}-]$} & {$[-\mathrm{n}-]$} & $-\varnothing$ \\
$/ * \beta /$ & {$[\beta-]$} & {$[-\beta-]$} & $-\varnothing$ \\
$/ * \mathrm{~s} /$ & {$[\mathrm{s}-]$} & {$[-\mathrm{s}-]$} & $-\varnothing$ \\
$/ * \mathrm{R} /$ & {$[\mathrm{R}-]$} & {$[-\mathrm{R}-]$} & $-\varnothing$ \\
$/ * \mathrm{~h} /$ & {$[\mathrm{h}-]$} & {$[-\mathrm{h}-]$} & $-\varnothing$ \\
$/ * 1 /$ & {$[1-]$} & {$[-1-]$} & $-\varnothing$ \\
$/ * \mathrm{~b} /$ & {$[\hat{\mathrm{b}}-]$} & {$[-\mathrm{b}-]$} & $-\varnothing$ \\
\hline
\end{tabular}

This study found the reconstruction of the phonemes protolanguage BBS obtained by a vocal proto of 5 pieces, namely/* i, * u, * e, * o, *a/. Based on the position of the vocal proto phonemes $/ * \mathrm{i} /$ is the front high vocal, $/ * \mathrm{u} /$ is a high-back vocal, $/ *_{\mathrm{e}} /$ is the front-middle vowel, $/ *_{\mathrm{o}} /$ is the rear-center vowel, and $/ * \mathrm{a} /$ is a low-middle vocal. The distribution of proto phonemes vocals above can be present in all positions, namely: the starting position, the middle, and the final position. Proto of the group consonant BBs obtained as much as 16 pieces, namely $/{ }^{*} \mathrm{p},{ }^{*} \mathrm{~b},{ }^{*} \mathrm{t},{ }^{*} \mathrm{j},{ }^{*} \mathrm{k}$, $*_{\mathrm{g},} *_{\mathrm{d}}, * \hat{\mathrm{b}},{ }^{*} \beta, *_{\mathrm{s}}, * \mathrm{~h}, *^{*},{ }^{*} \mathrm{~m},{ }^{*} \mathrm{n}, *_{\mathrm{y}}, * \mathrm{R} /$. Based on its position proto phonemes consonant/* p/is the bilabial plosives unvoiced, $/ *$ b/is bilabial sound; $/ * \mathrm{t} /$ is an unvoiced alveolar plosives; $/ * \mathrm{~J} /$ is an voiced palatal plosives; $/ * \mathrm{k} /$ is a silent velar plosives, $/ * \mathrm{~g} /$ is a sound velar plosives; $/ * \mathrm{~b} /$ is the implosive bilabial. Based on the results of the reconstruction of $\mathrm{BBs}$ there is no unvoiced palatal consonant $/ \mathrm{c} /$. Thus, the number of phonemes on BBs amounted to 21 pieces.
[1] Nazar, Asrul. 2014. Rekonstruksi Fonem Proto Kelompok Bahasa Cia-cia: Tinjauan Linguistik Historis Komparatif: Tesis. Pascasarjana Unhas.

[2] Gordon, Raymond G., Jr. (ed.). 2005. Ethnologue: Language of The World Fifteenth Edition. Dallas, Tex.: SIL International.

[3] Badan Pengembangan dan Pembinaan Bahasa. 2016. Hasil Penelitian Pemetaan Bahasa Daerah.

[4] Crowley, Terry. 1987. An Introduction to Historical Linguistics. Papua New Guinea: Universty of Papua New Guinea.

[5] Jeffers, R.J. and I Lehiste. 1979. Principles and Methods for Historical Linguistics. Cambridge, Massachusetts: The MIT Press.

[6] Keraf, Gorys. 1991. Linguistik Bandingan Historis. Jakarta: PT Gramedia Pustaka Utama.

[7] Machmoed, Hamzah A. 2014. Rekonstruksi Proto Gorontalo. Prosiding Kimli, Lampung.

[8] Mahsun. 2012. Metode Penelitian Bahasa (Tahapan Strategi, Metode dan Tekniknya) Edisi Revisi. Jakarta: PT Raja Grafindo Persada.

[9] Blust, Robert. A. 1977. The Soboyo Reflexe of Proto Austronesia. In Historical Linguistics In Indonesia Part. I NUSA 10: 21-30. Jakarta: Badan Penyelenggara Seri Nusa. 